\title{
Materials Development in the Colombian Context: Some Considerations About Its Benefits and Challenges
}

\section{Desarrollo de materiales en el contexto colombiano: algunas consideraciones acerca de sus beneficios y desafíos*}

\section{Bertha Ramos Holguín} ramos.bertha@gmail.com

\author{
Jahir Aguirre Morales \\ jahiraguirre@gmail.com \\ Universidad Pedagógica y Tecnológica de Colombia
}

Materials development is a field of study which has recently acquired significant importance in the Colombian context due to the fact that teachers, as materials developers, consider materials development as an area of knowledge that helps them to improve their teaching practices. However, the rationale, the gains as well as the challenges that drive materials designers have not been explored enough in Colombia. This article aims to provide some general considerations about the benefits teachers, as material developers, will obtain and some of the shortcomings which may emerge along this process. Finally, the authors discuss some implications for teachers, students, and teacher education programs.

Key words: Colombian education, foreign language teaching and learning, materials development

El desarrollo de materiales es un área de estudio que ha adquirido recientemente gran importancia en el contexto colombiano dado que los profesores como diseñadores de materiales han empezado a reconocer el diseño de materiales como un campo de conocimiento que ayuda a mejorar sus prácticas docentes. Sin embargo, la justificación, las ventajas y las desventajas que deben guiar a quienes diseñan materiales son aspectos que no han sido suficientemente explorados en Colombia. En este artículo se

* Received: January 8, 2014. Accepted: August 12, 2014.

How to cite this article (APA $6^{\text {th }}$ ed.):

Ramos Holguín, B., \& Aguirre Morales, J. (2014). Materials development in the Colombian context: Some considerations about its benefits and challenges. HOW, A Colombian Journal for Teachers of English, 21(2), 134-150. 
pretende dar a conocer algunas consideraciones generales acerca de los beneficios que los profesores que diseñan materiales pueden obtener y ciertos inconvenientes que emergen a lo largo del proceso. Finalmente, los autores discuten algunas implicaciones para los profesores, los estudiantes y los programas de licenciatura.

Palabras clave: Desarrollo de materiales, educación en Colombia, enseñanza y aprendizaje de lenguas extranjeras

\section{Introduction}

Over the past few years, English language teaching in Colombia has been ruled by the National Bilingual Program which is intended to make Colombian citizens bilingual in Spanish and English by 2019 (Ministerio de Educación Nacional as cited in Usma, 2009). Educational institutions have been implementing strategies to abide by and fulfill the expectations of this Colombian national policy. In doing so, the institutions have increased the number of hours for teaching English, started to work with content-based instruction, and adopted English textbooks. "It is common to see text publishing conglomerates offering teacher proof training programs, promoting the traditional one-size-fits-all methodological model, and commercializing educational materials like textbooks and software" (Álvarez, 2008, p. 7).

Many educational institutions have taken for granted that commercial textbooks supply what is needed to help a language learner to become bilingual. However, these textbooks, which are not created for a specific context, may produce a negative effect on students' motivation due to the fact that they usually provide content which tends to generalize students' needs and do not fulfill both learners' and teachers' expectations (Núñez \& Téllez, 2008). In this sense Harmer (2012) affirms that students engage in content which is often about themselves and their lives and in this way they learn better.

Therefore, in the Colombian context, there is the need to explore the effects of designing materials by Colombian teachers for their specific contexts. However, this leads teachers to an extra workload which, as expressed by Núñez, Téllez, and Castellanos (2012), is not always supported by institutions. As a result, one of the multitasking activities that teachers have to perform is materials development.

Teachers have to adapt themselves to the specificities a class has. Large classes, reviewing lessons, quizzing and re-quizzing, students with learning disabilities, courses with diverse language level, and make up activities for those students who fall behind are just a few of the challenges teachers frequently face. One way for teachers to tackle this situation is by adapting or designing materials as part of their lesson planning. In doing so, teachers are not far away from being materials developers. It is a fact that "teachers throughout the world need little training, experience, and support to become materials writers who can produce imaginative 
materials of relevance and that appeal to their learners" (Tomlinson, 2003, p. 4). It is also known that "developing materials for EFL/ESL [English as a Foreign/Second Language] classrooms should not be viewed as a task confined to textbook developers" (Núñez, Pineda, \& Téllez, 2004, p. 129). Also, as stated by Núñez and Téllez (2009), most EFL teachers have the skills to develop their own materials based on their knowledge regarding language teaching and on their experience as language educators. Teachers are the ones who really know how to assess their students" needs. To do so teachers can explore "what the learners know and can do, and what they need to learn or do" (Graves, 1997, p. 12).

This article explores, on the one hand, some of the benefits for English teachers and their students when the material brought into class is conceived by keeping in mind some of the specificities of the teaching target population. On the other hand, new challenges emerge for English teachers as materials developers. Thus, the purpose of this paper is to provide teachers information of the pertinent implication involved in materials design.

The content of this article also attempts to provide some initial reasons to devise in-house materials. Some of these reasons are associated with the stimulation of the learning process, teachers as dynamic agents of change and the need for having a more comprehensive environment for education. Likewise, some benefits of designing materials are shared. In the same way, this article shows how these benefits affect teachers and learners. These benefits are associated with teachers' empowerment, students' motivation, inclusion of students' opinions, appropriateness of the material, attainable teaching, and learning objectives, among others. Furthermore, this article tries to exhibit some of the challenges materials developers come across: satisfying multiple needs and wants, accounting for cultural consciousness and argumentative skills in the materials, sponsorship, carrying out a systematic evaluation, plagiarism and categorization, and saving information for future use. As a final point, this article attempts to share some conclusions and foresee certain implications that teachers as materials developers in the Colombian context encounter. All this to conclude that materials developed by teachers tends to be more appealing to students' contexts and their needs as well as they fulfill students' expectations more effectively.

\section{Reasons to Design Materials}

In the Colombian context Núñez, Téllez, Castellanos, and Ramos (2009) have addressed some of the reasons why teachers should develop their own materials. Their thoughts can be summarized in the two ideas that follow: First, materials devised by English teachers tend to stimulate students' learning process because they introduce changes and new ideas, they invite students to take part in demanding learning activities, and they attract students' attention. Second, teachers who develop materials improve their teaching insights, practices 
and procedures whilst they are being active agents of change. As a result, materials development can be considered a field of study that seems to be beneficial for both learners and teachers.

To the aforementioned ideas, we can add three more reasons for teachers to develop their own materials, namely: They are (1) the connection between innovation and research that can be made through the development of materials, (2) the possibility to work towards a more inclusive environment for education with the materials that we develop, and (3) the opportunity to close the gap between home and school. These ideas will be discussed in the following paragraphs.

The first reason has to do with the systematic process used to collect and analyze information that can lead teachers to design materials that are innovative for their context. Needs analysis, used to gather information, is the basis not only for syllabi design but also for materials development (Núñez et al., 2009; Pineda \& Núñez, 2001). After this step has been reached, there is the need to pilot and evaluate those materials so that they can be adjusted and improved. This procedure helps to build a coherent process for materials development. By following this route, teachers move from just intuition for materials development toward an informed decision to devise materials. Thereby, materials development gains the characteristics of a systematic research process. In this sense, Núñez et al. (2012) report the connection that the Masters' Program in Education with Emphasis on English Didactics candidates, in a Colombian private university, make between materials development as an innovation in their context and research. The authors highlight how these MA candidates build up the instructional design of their research projects based on a materials development framework. This has helped them to link innovation and research.

The second reason has to do with the possibility to work and create a more inclusive environment for education. It is a fact that in Colombian classrooms, as Aguirre and Ramos (2011) mention, "there is a mixture of students in the classrooms coming from different backgrounds, socioeconomic statuses, ethnicities and religious beliefs" (p. 170). In addition, students have diverse learning styles, they learn at a different pace and the command of the language varies (Núñez et al., 2009). Besides the previous facts, the Colombian General Education Law 115 (Congreso de Colombia, 1994) suggests that the government delegate the responsibility of assisting people with any disability to educational institutions. A typical Colombian classroom has, on average, from 30 to 50 students. Most students in a classroom are regular students without any disability. However, some others have a learning disability which could be related to language deficit disorder, deafness, and cognitive disorder, among others. A few students could be classified as gifted students (students whose learning abilities are above average). This entire situation, a class with diverse kinds of learners, makes Colombian classrooms spaces for inclusive education. 
This kind of population that attends Colombian schools nowadays demands teachers who adapt their methodologies to cope with diverse students' needs in a classroom. It is our belief that by creating their own materials, teachers can manage these new demands. UNESCO (2009) pinpoints the need to support the great diversity of learners and to enhance the quality of education by training teachers, promoting learning-centered methodologies, and developing proper textbooks and learning materials. In this sense, one of the teachers' roles relies on adaptability. This adaptability deals with the capability of the teachers to adapt any material and bring it into their classrooms and it also relates to the knowledge of the teachers to design materials for the needs of diverse populations. It is well known that most English teachers tend to adapt materials to regular students' needs. However, now the population is more diverse and teachers need to address issues related to inclusive education in their classrooms. Teachers should move from adapting materials (to modify already created materials by omitting, adding, reducing, extending, and replacing activities as Maley, 1998, suggests) to designing materials (to create material from scratch. These materials are usually more related to students' local needs with valid methodological awareness [Xiaotang, 2004]) which diminishes discrimination and considers target population needs and abilities. Although teachers have to pay attention to particularities of the context in which they work when designing materials, they should account for universal Second Language Acquisition (SLA, hereafter) principles that underpin the design of material for local context as stated by Tomlinson (1998).

In this way, neither the teachers nor the students have to adapt to the materials but the materials have to be thought out and developed from the beginning for the real students' needs, namely regular, disabled, or gifted students. As Gamboa (2009) suggests, inclusion does not accept a parallel curriculum; rather, new or adapted strategies, methodologies and practices need to be applied to all the students in a classroom.

The third reason is related to the fact that teachers are always looking for strategies to involve parents in their children's learning process. Parental involvement relates to a set of strategies to engage parents in students' learning tasks inside or outside the schools, for students to obtain academic gains (The No Child Left Behind Act, 2002). When materials are designed by teachers, there is a strong possibility to include tasks that can be done at home with the help of students' parents. This may help teachers close the gap between home and school and then, involve and engage students' families in the school context. Researchers such as Moll and Gónzalez (2004) have demonstrated the benefits of getting to know families well and then building connections in teaching with families. This can be done by creating a variety of activities or curricular units that relate to students' home context and that students can develop with their parents' help. McIntyre (2007) mentions that finding out about families' interests, hobbies, talents, and work can help devise a list of tasks to involve families which in turn may be positive for students' learning outcomes. 


\section{Some Benefits of Developing Materials}

Developing materials can be beneficial for both teachers and learners. In the following lines, we tackle some of the gains of this process. The benefits for teachers are the teachers' empowerment, increase of students' motivation, the need to listen to students' voices to consider their needs, the requirement of contextualizing teaching materials, the awareness teachers can benefit from in terms of having a holistic view of education, and both the theoretical knowledge and the practical skills they acquire by developing materials.

Empowering teachers "to theorize from their practice and practice what they theorize" (Kumaravadivelu, 2007, p. 16) is one of the main benefits for teachers as materials developers. Materials development is a way to put into practice theories and principles of second language acquisition. Teachers do so by:

Giving clear instructions, making strategies explicit, balancing and organizing pre and post activities, providing variety in the activities, delaying activities for constructing knowledge or engaging in very complex activities, and including communicative activities appropriate for students' current language performance/command of English. (Núñez et al., 2012, p. 29)

It helps teachers to construct, reconstruct, and deconstruct theories based on their real practices. In such a way, teachers, as materials developers, recognize the knowledge they construct with their students, which is valid and useful in their teaching practices.

The experiences teachers offer to students affect students' motivation positively or negatively, plus, materials designed by teachers play a key role in providing friendly experiences in the classroom (Harmer, 2012). Then, materials conceived by teachers are intended to increase students' motivation, which also helps to decrease anxiety. This kind of materials fits in a much better way with the students' needs, since the topics and the type of exercises are designed considering students' previous knowledge and expectations. This creates a friendlier environment for foreign language learning. As part of the conclusions of a research study carried out by Subaşi (2010) related to two potential sources of anxiety of Turkish learners of English in oral practice, the researcher found out that EFL language teachers need to identify students having high anxiety and low self-esteem so that they can create a supportive and friendly atmosphere to practice the target language in.

One of the most relevant sources for teachers to develop their materials from is students' opinions. These opinions need to be heard in order to improve the content, the topics, the kind of exercises, the instructions, and so forth, of the in-house materials. This is one way to acknowledge students' voices and recognize their status as the center of the teaching-learning process. Tomlinson (2003) mentions that the future of materials development should guide writers to not only respect, but learn more about learners' interests and needs. Listening to students' voices may be seen as a way to respect them and their opinions in the 
teaching-learning process. In a case study related to the validation of the teaching of English within the theory-practice alternance or dual model through the implementation of a series of English textbooks, Núñez (2010) claimed that one of the fundamental aspects that facilitated the validation and the usefulness of this in-house material was students' voices that helped to design contextualized materials, meeting students' as well as the institution's needs.

Considering that students' learning needs are of paramount importance in any classroom in order to accomplish a teaching-learning objective, Cárdenas (2000) argues that "learning needs are not limited solely to language aspects. Learners have intellectual and emotional needs too" (p. 9). The development of materials allows teachers to focus not only on the students' language needs, but also on their emotional needs. In terms of language needs, teachers as material creators know beforehand the students' language level which helps them to develop material with realistic language objectives. To consider emotional needs material developers use topics that are commonplace for the target population. Furthermore, they acknowledge students' cultural heritage validating their home culture. In this sense, Block (1991) argues that teachers can respond to the geographical and cultural context of the learners, draw upon the topical — which is important to the students in referring to current events - and provide a personal touch, which also assists material devisers to accomplish emotional needs. In the same perspective, Kumaravadivelu (2007) talks about the magnitude of sensitizing practitioners to their students' social and cultural background and needs. This awareness process emerges when teachers develop their own teaching materials as they become skillful observers of their students' realities. By the same token, Núñez et al. (2012) state that when in-service teachers design materials, they relate to their students' needs and requirements. Therefore, materials development sustains their professional development and the reflection on what teachers do as professionals. Needless to say, teacher as materials developers also need to bear in mind that besides the students' needs there are some others that must be considered. Harwood (2010) classifies these needs as learners', teachers', educational authorities', and stakeholders' (parents and sponsors) needs. Equally important, Pineda (2000) asserts that multiple instruments ought to be used to collect useful information about the needs from all agents involved so, the process is more valid.

Another benefit of teachers devising their own materials relates to the fact that materials can be more contextualized. Tharp, Estrada, Dalton, and Yamauchi (2000) talk about instructional contextualization. This term relates to the connection that can be made between the topics pupils are supposed to learn according to the syllabus at school and their background. Knowing students' needs, teachers are more willing to create tasks in which learners can share their experiences and previous knowledge. Then, the tasks proposed in the materials developed by teachers can entail topics closely related to students' context such as their home, community, school norms, and knowledge. 
To have clear objectives from the very beginning, based on needs analysis, helps materials developers to focus their work, attention, and efforts on handling students' needs. Stern (1992) presents a typology of goals that guides materials developers while they conceive their materials. This typology is divided into four categories. The first category relates to "Proficiency goals include general competency and mastery of the four linguistic skills;" the second one accounts for "cognitive goals that include mastery of linguistic and cultural knowledge;" the third category is about "affective goals which involve achieving positive attitudes and feelings about the target language," and the last category includes "transfer goals that have to do with how to learn to meet future challenges" (p. 17). Although this typology of objectives is helpful to start creating materials, it is by no means the only ones teachers can adopt since depending on the context, goals can be widened or narrowed down to meet the specific requirements of the institution.

Before setting the goals there are some basic questions material developers need to answer in order to establish attainable objectives. These questions are: What kind of materials do I plan to carry out? (a quiz, an exam, a poster, a lesson, a workshop unit, a textbook, a workbook, a flashcard, an exercise, etc.). Who am I going to work with? (alone, with a partner, with a team, etc.). Why do I design material? (to accomplish students' needs, to innovate, to motivate students, to complement a textbook or a lesson, to review a topic, etc.). By considering the aforementioned ideas by Stern (1992) and by answering the previous questions, teachers, as materials developers, can be aware of all the possible dimensions (cognitive, affective, and metacognitive) implied in the teaching of a foreign language, which in turn are the platform for the design of any kind of material. In this way, teachers manage a more holistic view of education that positively affects students' learning.

Giving more control to teachers, engaging students in learning, acknowledging students' needs, considering students' background in the teaching material, and offering an integrated view of education lead materials developers to reflection. Rodgers (2002) argues that reflection is composed of four main steps: observation, description, collection and analysis of data, and the decision making processes. When teachers use the materials they create, they enroll in a cyclical and systematic process of constant reflection upon the usefulness of their own materials. Harmer (2012) establishes that "it is important for teachers to keep a record of what works and what doesn't (for the class and for individual students). Reflective teachers do this anyway, and it helps them to design what to do next" (p. 99). This process gives teachers an active role that empowers them to make decisions about their material and the way it fits students' needs and learning settings (Núñez et al., 2009).

Achieving skills to develop materials is a relevant advantage for teachers. Núñez et al. (2012) recognize the following abilities teachers reach: the design of balanced layout, the acknowledgement of sources, the pacing principles, the proof-reading capacity, and the 
improvement in language proficiency, among others. The aforementioned aspects consider inclusiveness and empowerment. These two aspects help teachers to have more desirable outcomes in their classrooms.

\section{Some Challenges of Developing Materials}

There are some problematic areas teachers, as materials developers, may find difficult to deal with. These problems relate to some of the difficulties not only of the task of devising materials but also of the further inclusion of the realities of students in the materials that are developed. Although the outcomes students and teachers get out of the development of materials designed by teachers are beneficial, there are some issues to overcome. They are satisfying multiple needs, responding to cultural consciousness and argumentative skills in the materials, plagiarism, institutional support and sponsorship, a systematic evaluation process, language and layout quality in the materials, and categorization and storage of the information. These items could be evident for teachers who are experienced in developing materials, but if they are not overseen, the efforts to create materials can be wasted.

Satisfying the multiple requirements to develop materials may be a shortcoming worth analyzing by teacher as materials developers. Tomlinson (2003) suggests that when developing materials, diverse needs and wants ought to be considered. Students' and teachers' needs as well as administrative requirements must be addressed in order to consider all the agents involved in the process of developing materials. Thus, learners, teachers and administrators have to be consulted while the materials are being conceived (Tomlinson, 2003). Integrating the feedback provided by these agents makes the material more suitable for the specific context where it is developed.

Accounting for cultural consciousness in the materials devised by English teachers is another constraint. Kumaravadivelu (2007) refers to global cultural consciousness as a cluster of cultures learners wish to target which can help them to understand the broader network of cultural communities. This cultural cluster he talks about may be hard to include in the classroom unless teachers have a very clear concept of what inter-culturality and cultural awareness are and how these concepts can be put together in the teaching materials they develop.

Another difficult issue to achieve is the need to increase argumentative skills through the material that is designed by teachers. Argumentative skills are defined by Augustinienë, Bankauskienë, \& Ėiuèiulkienë (2010) as the capability to defend ideas and create consensus in controversial topics. The development of argumentative techniques is proposed by different authors such as Castro (2002), Pineda (2003), and Wessling (1999) as a strategy to enhance the analytical abilities of students. If a person masters the principles of a sound argument, she or he will also be able to understand other people's arguments; this means that one might be able 
to understand what the lines of argumentation are and if they qualify as arguments in a discussion. In this respect, Núñez and Téllez (2012) defend the idea that knowing how to argue is a difficult task as it requires profound knowledge about argumentation. The authors further suggest that one of the teachers' roles is to guide students to build up their argumentative skills. This will necessarily contribute to the avoidance of biased or ethnocentric arguments for they are usually ill constructed. Argumentation, thus, will help transcend subjectivity and include other people's perspectives in the discussion of a given theme. However, achieving this kind of argumentative skills requires a lot of effort from the teacher because it implies constructing critical thinking skills. Argumentation becomes a very useful tool for critical thinking, and critical thinking constitutes one of the bases for emancipatory education. The concept of emancipator education was discussed by Freire (1970). It relates to the fact of forming critical consciousness in individuals. It is based on inquiring about the causes of social and political issues in order to promote strategies that can change the society.

Institutional support and sponsorship are two issues that are difficult to handle. Akbari (2008) points out that "teachers operate within tight administrative frameworks" (p. 645). The author also mentions that "teachers in many contexts are not different from factory workers in terms of their working hours" (p. 646). In the Colombian context, on the one hand, many institutions may not be willing to support their teachers as material developers as it may affect the regular duties (parent teacher conferences, lesson planning, homeroom teaching, recess duty, etc.) that teachers are supposed to help with. Materials creation generates extra work for teachers due to the fact that most teachers are hired to teach lessons instead of devising materials. It is a fact that developing in-house material for students takes a lot of time and dedication. One teacher can devote from four to six hours developing one or two pages of material to bring into the classroom. On the other hand, budgetary concerns can diminish once teachers, as materials developers, pilot, evaluate, and show the positive outcomes of the use of in-house material. These two aspects need to be considered by teachers and institutions before starting the process of developing materials.

Carrying out a systematic evaluation of the materials is another challenge for teachers as material developers. An effective and informative evaluation of the material has to report not only students' feelings and attitudes towards the materials, but also their language achievements. As Tomlinson (2011) states:

For materials to be valuable, the learning points should be potentially useful to the learners and the learning procedures should maximize the likelihood of the learners actually learning what they want and need to learn. It is not necessarily enough that the learners enjoy and value the materials. (p. 3)

In the same line, Tomlinson (2003) further suggests that materials must be evaluated through systematic, rigorous, and principled procedures. He asserts that the evaluation of 
materials should answer the following questions: what degree, how and why they facilitate language learning. Then, materials designed by teachers have to go through a systematic process of evaluation so that real outcomes can be perceived.

When teachers design materials they expect their material to be innovative, creative, and meaningful. In this process, teachers access diverse sources of information such as newspapers, magazines, textbooks, databases, web pages, and so forth in order to learn more about the specificity of a given topic. It is easy to forget the sources where the information was taken from. This may lead to plagiarism.

Teachers conceiving their materials should be aware of the fact that although they know the target language, there is also need to proofread the material. This proofreading allows the material to have a much better language quality. In this way, teachers as materials developers avoid the first sight deficiency view which, according to Wyatt (2011), holds that learners need to be protected from teachers' deficiencies as materials designers. Language quality directly affects students' learning outcomes. So, materials developers need to avoid that deficiency.

In addition to language quality, layout quality also affects the content of the material. Materials developers should keep in mind that materials cannot be overwhelmed with written text. There should be a balance among pictures, charts, written text, colors, type of fonts, and any other items included in the material. This balance helps to attract and maintain students' attention. This happens because in a regular classroom, students possess multiple intelligences and the more variety students perceive in the material, the more chances they have to learn. Altan (2012) suggests that lack of teaching material that fosters multiple intelligences is a problematic issue in many education systems because students have different intelligences but these are not addressed in classrooms.

Another issue to overcome is the lack of knowledge and information about materials development as a field of study and its implications in the processes of learning and acquisition of a foreign language (Núñez et al., 2012). Although authors such as Bolitho (2003), Maley (2003), Tomlinson (2008), Tomlinson and Masuhara (2010), among others, have been interested in looking at materials development as a scientific discipline, there is still the tendency to think that it is a technical activity anyone can perform. This is usually the case of the materials development in the Colombian context where teachers, institutions, and policymakers tend to belittle the positive impact that material has on students' achievements. As a matter fact, some Colombian public institutions are satisfied with only having the language teachers as input in the English classes.

Finally, categorizing and saving information in an organized way represent a challenge for the material that teachers create. Although there is not an academic source that suggests a way for categorizing information for materials developers, one fruitful way to do it is by labeling 
the material. First, materials need to be categorized and labeled by following the same pattern, for example: (quiz-greetings-first grade). This example was labeled by following this pattern: general category (quiz), language function or topic (greetings), and target population (first grade students). This helps, on the one hand, to construct a bank of materials that can be reused once they are piloted and evaluated. On the other hand, it reduces the risk of designing material that is never piloted or evaluated plus it avoids working on material for one time use.

\section{Conclusions}

The main objective of this paper was to provide teachers interested in designing materials information about some implications involved in materials design; in doing so, this manuscript explored three main parts in this process: reasons, benefits, and challenges. This article stated that the main reasons for teachers to design materials are related to the necessity of engaging students in language learning through systematic innovations, the need for teachers to become agents of change, the opportunity for teachers to work towards a more inclusive education, and the chance to provide more spaces for parents to participate in their children's learning processes.

The text continued with a review of the benefits for both teacher and learners. Developing materials is valuable for teachers as they become aware of all the principles that underlie the teaching/learning processes. Teachers also understand and learn from their students' needs and develop skills to design materials. For learners it is worthy since they engage easily in the content of the material because it is closed related to their context. Later on, this article analyzed the issues teachers have to overcome when designing materials: meeting diverse needs, achieving high quality in the materials produced, finding a supportive environment, accomplishing an efficient evaluation process of the materials, and becoming aware that designing materials is a scientific discipline in language teaching.

All the aforementioned aspects help teachers to be aware of what it implies to design materials. "Developing materials is a systematic process, yet it is not a complex one" (Núñez et al., 2012, p. 28). By considering the information presented in this article, teachers can make informed decisions in regard to materials design. In this way they may avoid stumbling during the process of devising materials.

\section{Implications}

In the next lines, implications for EFL teachers, educational institutions, and educational authorities will be shared. In terms of the implications for EFL teachers, the need to consider materials development as an area of research and the usefulness materials development has to review students' outcomes are discussed. For educational institutions, it is suggested that 
materials development be included as a course in language teaching programs. Finally, for educational authorities more knowledge about the impact of materials development is required.

Materials development should be based not only on teaching experiences but also on research agendas that see materials design as an area of research that may help teachers improve teaching and learning conditions. Theories of second language acquisition and development inform materials development. In the same way, a systematic research process aimed at developing materials can strengthen, shape, or reshape language teaching/learning principles. That is to say, when teachers create, apply, and evaluate materials, they have the opportunity/possibility to validate and/or restate teaching/learning principles. In doing so, teachers as material developers can be very empowered to change the current conditions of their classrooms as they can experience and even construct diverse teaching and learning principles.

Some teachers do not recognize that they have endless choices when developing their own materials. These choices have a powerful impact on students' language learning success or failure. Materials development provides teachers with the possibility to review their choices and the effect they have on the students' performances.

An important consideration that benefits not only language teachers in Colombia, but also teachers and educators internationally is to report the findings of pedagogical or research experiences related to materials development. This account cannot be limited to anecdotal evidence about the usefulness of materials. It needs to be systematically supported. It is through informed reports and research in this area that better materials can be produced in the future.

The fact of being able to select the topics for the materials helps teachers as materials developers to guide students to have a better understanding in regard to issues that affect their Colombian context. It is a fact that "most of the topics one encounters in commercially prepared textbooks deal with harmless issues such as travel, shopping, holydays, and food recipes, leaving little room for social transformation and political-awareness raising" (Akbari, 2008, p. 647). In order to avoid addressing these harmless issues, materials developers can focus on topics related to displacement, discrimination, bullying, inner cities sub-cultures, values, and so on. By including and working with these topics, teachers can build up social awareness. After carrying out a research study related to the topics of reading passages in English language teaching course books, Arkian (2008) found out that topics related to love and values can help to eradicate violence in any society through social awareness.

Foreign language programs should not underestimate the value of courses on developing materials. In other words, courses on materials design cannot be inserted as part of a didactics or methodology class as it commonly happens. On the contrary, pre-service teachers a well as 
in-service teachers need to develop expertise in materials design as it helps them to understand language acquisition processes (Tomlinson, 2003). In this sense, Tomlinson and Masuhara (2010) argue that one of the most effective ways to help teachers not only to understand and apply theories of second language acquisition but also to grow professionally and personally is by providing them with experiences related to developing materials.

Lastly, educational authorities need to gain more knowledge about the positive impacts of materials development on students. In this way, policymakers would be more willing to support teachers working on materials design. Therefore, teachers would enroll more easily in materials development which results in teachers' professional growth.

\section{References}

Aguirre, J., \& Ramos, B. (2011). Fostering skills to enhance critical educators: A pedagogical proposal for pre-service teachers. HOW, A Colombian Journal for Teachers of English, 18(1), 169-197.

Akbari, R. (2008). Postmethod discourse and practice. TESOL quarterly, 42(4), 641-652.

Altan, M. (2012). Introducing the theory of multiple intelligences into English language teaching programs. Pamukekale University Journal of Education, 32(2), 57-64.

Álvarez, A. (October, 2008). Educational commercialism: Is it overtaking EFL in Colombia. ASOCOPI Newsletter.

Arkian, A. (2008). Topics of reading passages in ELT coursebooks: What do our students really read? The Reading Matrix, 8(2), 95-198.

Augustinienë, A., Bankauskienë, N. \& Èiuèiulkienë, E. (2010). Argumentative competence: How to develop it? Retrieved from https://www.ntnu.no/wiki/download/attachments/8325736/ Deliverable+7a+April+2010.pdf

Block, D. (1991). Some thoughts on DIY materials design. ELT Journal, 45(3), 211-217.

Bolitho, R. (2003). Materials for language awareness. In B. Tomlinson, (Ed.), Developing materials for language teaching (pp. 422-425). London, UK: Continuum.

Cárdenas, M. (2000). Producing materials to respond to children's local needs. ELT Conference 2000, Bogotá, Colombia.

Castro, F. (2002). Enseñanza y aprendizaje de la competencia intercultural en el aula de grupos multilingües [Teaching and learning of intercultural competence in the multilingual classroom]. ASELE, Actas XIII, 217-227.

Congreso de Colombia. (1994). Ley General de Educación 115 [Colombian General Education Law 115]. Retrieved from http://www.alcaldiabogota.gov.co/sisjur/normas/Norma1.jsp?i=292

Freire, P. (1970). Pedagogy of the oppressed. Harmondsworth, UK: Penguin.

Gamboa, D. M. (2009). Aproximación a un estado del arte sobre las necesidades educativas especiales de los niños sordos en latinoamérica [Approximation to a state of the art on the special educational needs of deaf children in Latin America] (Undergraduate monograph). Universidad de la Sabana, Bogotá. 
Bertha Ramos Holguín and Jahir Aguirre Morales

Graves, K. (1997). Teachers as course developers. Cambridge, UK: Cambridge University Press.

Harmer, J. (2012). Essential teacher knowledge: Core concepts in English language teaching. London, UK: Pearson Education.

Harwood, N. (2010). English language teaching materials: Theory and practice. New York, NY: Cambridge University Press.

Kumaravadivelu, B. (2007). Cultural globalization and language education. London, UK: Yale University Press.

Maley, A. (1998). Squaring the circle: Reconciling materials as constraint with materials as empowerment. In B. Tomlinson (Ed.), Materials development for language teaching (pp. 279-294). Cambridge, UK: Cambridge University Press.

Maley, A. (2003). Creative approaches to writing materials. In B. Tomlinson, (Ed.), Developing materials for language teaching (pp. 183-198). London, UK: Continuum.

McIntyre, E. (2007). Story discussion in the primary grades: Balancing authenticity and explicit teaching. The Reading Teacher, 60(7), 610-620.

Moll, L., \& González, N. (2004). Engaging life: A funds-of-knowledge approach to multicultural education. In J. A. Banks (Ed.), Handbook of research on multicultural education (pp. 699-715). San Francisco, CA: Jossey-Bass.

No Child Left Behind Act. (2002). Retrieved from http://www2.ed.gov/admins/lead/account/ nclbreference/reference.pdf

Núñez, A. (2010). The teaching of English within the theory-practice alternance model. In Dirección de Investigaciones y Estudios Empresariales Fundación Universitaria Empresarial de la Cámara de Comercio de Bogotá (Ed.). Innovación y competitividad: memorias de la Jornada de Investigación 2010. Bogotá, CO: Uniempresarial.

Núñez, A., \& Téllez, M. F. (2008). Meeting students' needs. Enletawa Journal, 1, 65-68.

Núñez, A., \& Téllez, M. F. (2009). ELT materials: The key to fostering effective teaching and learning settings. PROFILE Issues in Teachers' Professional Development, 11(2), 171-186.

Núñez, A., \& Téllez, M. F. (2012). Using debates in the classroom: A pedagogical strategy for the development of the argumentative competence in the teaching of English as a foreign language. Bogotá, CO: Publicaciones Universidad Externado de Colombia.

Núñez, A., Pineda, C., \& Téllez, M. F. (2004). Key aspects for developing your instructional materials. PROFILE Issues in Teachers' Professional Development, 5(1), 128-139.

Núñez, A., Téllez, M. F., \& Castellanos, J. (2012). A framework for materials development: A path for in-service teachers to build up the instructional design of their research projects. In A. Núñez, M. F. Téllez, \& J. Castellanos (Eds.), Teacher research on English didactics issues (pp. 17-30). Bogotá, CO: Publicaciones Universidad Externado de Colombia.

Núñez, A., Téllez, M. F., Castellanos, J., \& Ramos, B. (2009). A practical materials development guide for EFL pre-service, novice, and in-service teachers. Bogotá, CO: Editorial Universidad Externado de Colombia.

Pineda, C. (2000). La enseñanza de inglés con propósitos específicos [The teaching of English for specific purposes]. Bogotá, CO: Publicaciones Universidad Externado de Colombia. 
Pineda, C. (2003). Searching for improved EFL classroom environments: The role of critical thinking-related tasks. Bogotá, CO: Publicaciones Universidad Externado de Colombia.

Pineda, C., \& Núñez, A. (2001). Getting in touch with reality: An English curriculum to boost students' critical thinking skills and interest in global issues. HOW, A Colombian Journal for Teachers of English, 9, 34-39.

Rodgers, C. R. (2002). Seeing student learning: Teacher change and the role of reflection. Harvard Educational Review, 72(2), 230-253.

Stern, H. (1992). Issues and options in language teaching. Oxford, UK: Oxford University Press.

Subaşi, G. (2010). What are the main sources of Turkish EFL students' anxiety in oral practice? Turkish Online Journal of Qualitative Inquiry, 1(2), 29-49.

Tharp, R., Estrada, P., Dalton, S., \& Yamauchi, L. (2000). Teaching transformed: Achieving excellence, fairness, inclusion, and harmony. Boulder, CO: Westview Press.

Tomlinson, B. (1998). Materials development in language teaching (1 ${ }^{\text {st }}$ ed.). Cambridge, UK: Cambridge University Press.

Tomlinson, B. (2003). Developing materials for language teaching. London, UK: Continuum.

Tomlinson, B. (2008). English language learning materials: A critical review. London, UK: Continuum.

Tomlinson, B. (2011). Materials development in language teaching (2nd ed.). Cambridge, UK: Cambridge University Press.

Tomlinson, B., \& Masuhara, H. (2010). Research for materials development in language learning: Evidence for best practice. London, UK: Continuum.

UNESCO. (2009). Policy guidelines on inclusion in education. Paris, FR: Author.

Usma, J. A. (2009). Education and language policy in Colombia: Exploring processes of inclusion, exclusion, and stratification in times of global reform. PROFILE Issues in Teachers' Professional Development, 11(1), 123-141.

Wessling, G. (1999). Didáctica intercultural en la enseñanza de idiomas: algunos ejemplos para el aula [Intecultural didactis in language teaching: Some examples for the classroom]. In L. Miquel \& N. Sans (Eds.), Didáctica del español como lengua extranjera (pp. 267-281). Madrid, ES: Colección Expolingua.

Wyatt, M. (2011). Becoming a do-it-yourself designer of English teaching materials. Forum Qualitative Social Research, 12(1), 33-54.

Xiaotang, C. (2004). Current trends in syllabus design and materials development. Beijing, CN: Beijing Normal University.

\section{The Authors}

Bertha Ramos Holguín is an associate professor at Universidad Pedagógica y Tecnológica de Colombia. She holds an M.A. in Applied Linguistics from Universidad Distrital (Colombia). She belongs to the research group TONGUE. She has co-authored English textbooks, and published research articles related to English language teaching. 
Bertha Ramos Holguín and Jahir Aguirre Morales

Jahir Aguirre Morales is an assistant professor at Universidad Pedagógica y Tecnológica de Colombia. He holds an M.A. in English Didactics from Universidad de Caldas (Colombia). He belongs to the research group TONGUE. He has co-authored English textbooks, and published research articles related to English language teaching.

\section{Acknowledgments}

We would like to thank the editor and the two peer reviewers for suggesting valuable comments to improve this paper. 